\title{
Identifikasi Begomovirus yang Berasosiasi dengan Penyakit Kuning pada Mentimun di Jawa Barat dan Bali
}

\author{
Identification of Begomovirus Associated with Yellowing Disease \\ on Cucumber Plants in West Java and Bali
}

\author{
Rizki Haerunisa $^{1^{*}}$, Gede Suastika $^{1}$, dan Tri Asmira Damayanti ${ }^{1}$ \\ Diterima 04 Februari 2016/Disetujui 16 Maret 2016
}

\begin{abstract}
A survey conducted from several cucumber cultivation area of West Java and Bali found some plants showing yellow mosaic, vein banding, and stunting symptoms, caused by Begomovirus infection. This study aimed to detect and determine incidence of Begomovirus on cucumber plants, and analyze variation of Begomovirus coat protein gene in West Java dan Bali. Leaf samples from 50 plants were taken randomly from each location in Sumedang, Karawang, Sukabumi (West Java) and Tabanan, Gianyar, Klungkung (Bali). Disease incidence was determined based on serological assay using specific antiserum of Tomato leaf curl New Delhi virus (ToLCNDV) dan Squash leaf curl virus (SLCV). Incidence of ToLCNDV and SLCV were $28-100 \%$ and $30-80 \%$, respectively. PCR using Begomovirus degenerate primers successfully amplified coat protein gene about $\pm 550 \mathrm{bp}$. There were three Begomovirus species associated with yellowing disease on cucumber plant i.e Squash leaf curl China virus (SLCCNV), ToLCNDV, and Ageratum yellow vein virus (AYVV). Based on nucleotide sequences analysis, it was found that isolate SLCCNV had highest nucleotide homology with SLCCNV isolate Malaysia (EF197940) about 94.5\%, and was considered as a strain "China", whereas ToLCNDV has highest nucleotide similarity with ToLCNDV isolate Indonesia (AB613825) about 99.4\% and was considered as a strain "Indonesia". The AYVV sequences showed highest nucleotide AYVV isolate Nicotiana benthamiana from Indonesia (AB100305) about $92.1 \%$.
\end{abstract}

Keywords: Cucumis sativus, Dot immunobinding assay, Squash leaf curl China virus, Tomato leaf curl New Delhi virus

\begin{abstract}
ABSTRAK
Survei yang dilakukan di beberapa pertanaman mentimun di Jawa Barat dan Bali menemukan gejala mosaik kuning, daun keriting, penebalan tulang daun, dan kerdil akibat infeksi Begomovirus. Penelitian ini bertujuan untuk mendeteksi dan menghitung insidensi penyakit yang disebabkan oleh Begomovirus pada tanaman mentimun, serta menganalisis keragaman gen protein selubung Begomovirus di Jawa Barat dan Bali. Sampel daun diambil secara acak sebanyak 50 tanaman dari tiap lokasi pertanaman mentimun di Sumedang, Karawang, dan Sukabumi (Jawa Barat), Tabanan, Gianyar, dan Klungkung (Bali). Deteksi Begomovirus dan insidensi penyakit ditentukan dengan uji serologi DIBA menggunakan antiserum Tomato leaf curl New Delhi virus (ToLCNDV) dan Squash leaf curl virus (SLCV). Insidensi ToLCNDV dan SLCV berturut-turut berkisar 28-80\% dan 30-80\%. Deteksi dengan teknik PCR menggunakan primer universal Begomovirus berhasil mengamplifikasi gen protein selubung berukuran $\pm 550 \mathrm{pb}$. Hasil perunutan nukleotida menunjukkan terdapat tiga spesies Begomovirus yang menginfeksi tanaman mentimun di Jawa Barat dan Bali, yaitu Squash leaf curl China virus (SLCCNV), ToLCNDV, dan Ageratum yellow vein virus (AYVV). Isolat SLCCNV Bali memiliki kesamaan nukleotida dan asam amino terhadap isolat SLCCNV dari negara lainnya berkisar antara $89.8-94.5 \%$ dan $94.2-96.3 \%$, dan dikelompokkan ke dalam strain "Cina". ToLCNDV isolat Jawa Barat dan Bali memiliki kesamaan nukleotida dan asam amino berkisar antara 92.8-99.4\% dan
\end{abstract}

${ }^{1}$ Departemen Proteksi Tanaman, Fakultas Pertanian, Institut Pertanian Bogor

J1. Kamper, Kampus IPB Dramaga, Bogor 16680, Indonesia

e-mail: rizkihaerunisa2008@gmail.com (*penulis korespondensi) 
97.3-99.4\% dengan isolat ToLCNDV dari negara lainnya, tergolong ke dalam strain "Indonesia". Gen protein selubung AYVV Bali memiliki kesamaan nukleotida dan asam amino berkisar antara 89.5-92.1\% dan 94.7-95.2\%, dengan kesamaan tertinggi dengan isolat AYVV asal Indonesia yang menginfeksi Nicotiana benthamiana.

\section{Kata kunci: Cucumis sativus, Dot immunobinding assay, Squash leaf curl China virus, Tomato leaf curl New Delhi virus.}

\section{PENDAHULUAN}

Begomovirus merupakan kelompok virus dari famili Geminiviridae penyebab penyakit yang cukup penting pada beberapa komoditas hortikultura di berbagai daerah tropis maupun subtropis. Penyakit yang disebabkan oleh Begomovirus di Indonesia dilaporkan cukup banyak pada beberapa pertanaman hortikultura, seperti Pepper yellow leaf curl virus (PYLCV) dengan insidensi mencapai $100 \%$, dan epidemi penyakit terjadi di sentra-sentra produksi cabai di Indonesia terutama di Pulau Jawa pada tahun 2000 sampai 2003, Tomato yellow leaf curl virus (TYLCV) mencapai 50-70\% di Jawa Barat dan Jawa Tengah (Aidawati et al., 2005; Sulandari et al., 2006), dan Mungbean yellow mosaic India virus (MYMIV) yang menginfeksi kacang panjang dengan insidensi penyakit 80100\% di Jawa (Nurulita et al., 2015).

Mentimun (Cucumis sativus L.) merupakan salah satu jenis sayuran dari famili Cucurbitaceae yang sudah populer ditanam petani di Indonesia. Sejak tahun 2008, pertanaman mentimun di Klaten, Jawa Tengah, terserang penyakit daun keriting kuning. Daun mentimun mengalami mosaik hijau kekuningan. Penyakit tersebut berasosiasi dengan infeksi Tomato leaf curl New Delhi virus (ToLCNDV) dan telah menyebar ke beberapa kabupaten lainnya antara lain Bogor, Tegal, Sukoharjo, dan Sleman (Mizutani et al., 2011; Septariani et al., 2014). Penyakit kuning pada mentimun juga ditemukan di Kabupaten Tabanan, Provinsi Bali. Gejala yang timbul yaitu daun menguning dan adanya penebalan tulang daun (vein banding). Penyebab penyakit kuning di Bali berbeda dengan yang dilaporkan sebelumnya di wilayah Jawa Barat dan Jawa Tengah. Penyakit tersebut berasosiasi dengan Squash leaf curl China virus (SLCCNV) (Wiratama et al., 2015).
Deteksi dan identifikasi penyakit yang disebabkan oleh Begomovirus umumnya menggunakan teknik PCR (Polymerase Chain Reaction). Identifikasi Begomovirus pada tanaman tomat menggunakan primer Degenerate dan spesifik Gen AV1 menunjukkan bahwa semua contoh tanaman menghasilkan amplikon yang berukuran 780 bp (Santoso et al., 2013). Identifikasi terhadap Begomovirus menggunakan pasangan primer universal seperti PAL1v1978/ PAR1c715 berhasil mendeteksi MYMIV (Nurulita et al., 2015), primer pAV494/ pAC1048 berhasil mendeteksi PepYLCV (Sulandari et al., 2006), dan primer SPG1/SPG2 berhasil mengidentifikasi Tomato yellow leaf curl Kanchanaburi virus pada tanaman terung (Kintasari et al., 2013). ToLCNDV telah diketahui menginfeksi tanaman mentimun di Kabupaten Bogor dan Subang (Jawa Barat), Kabupaten Tegal dan Sukoharjo (Jawa Tengah), serta Kabupaten Sleman (DIY Yogyakarta), sedangkan SLCCNV diketahui menginfeksi tanaman mentimun di Kabupaten Tabanan (Bali). Keberadaan kedua virus tersebut perlu diketahui guna mengetahui sebaran virus sekaligus insidensi penyakit di beberapa daerah lainnya. Deteksi Begomovirus pada pertanaman mentimun dilakukan melalui teknik PCR dilanjutkan dengan proses perunutan DNA untuk mengetahui identitas spesies Begomovirus. Penelitian ini bertujuan untuk mendeteksi dan menghitung insidensi penyakit yang disebabkan oleh Begomovirus pada tanaman mentimun, serta menganalisis keragaman gen protein selubung Begomovirus di Jawa Barat dan Bali.

\section{BAHAN DAN METODE}

\section{Pengambilan Sampel Tanaman Mentimun}

Sampel tanaman mentimun sakit diambil dari pertanaman mentimun di 
Kecamatan Karawang Barat, Kabupaten Karawang, Kecamatan Cibadak dan Kecamatan Parung Kuda, Kabupaten Sukabumi, Kecamatan Ujung Jaya, Kabupaten Sumedang (Jawa Barat), serta Kecamatan Baturiti, Kabupaten Tabanan, Kecamatan Payangan, Kabupaten Gianyar, dan Kecamatan Klungkung, Kabupaten Klungkung (Bali). Setiap Kabupaten dipilih dua lahan mentimun sebagai tempat pengambilan sampel. Sampel yang dikoleksi yaitu daun mentimun yang menunjukkan gejala kekuningan sebanyak 50 daun pada setiap lokasi. Deteksi dan identifikasi virus dilakukan di Laboratorium Virologi Tumbuhan, Departemen Proteksi Tanaman, Fakultas Pertanian, Institut Pertanian Bogor.

\section{Deteksi Sampel Mentimun Terinfeksi Begomovirus}

Metode DIBA dilakukan menggunakan antibodi spesifik ToLCNDV dan SLCV (Deutsche Sammlung von Mikroorganismen und Zellkulturen) sesuai metode yang digunakan Anggraini dan Hidayat (2014). Sebanyak $0.1 \mathrm{~g}$ sampel digerus dalam tris buffer saline (TBS) dengan perbandingan 1:10 (b:v) (TBS: Tris-HCl $0.02 \mathrm{M}$ dan $\mathrm{NaCl} 0.15$ $\mathrm{M}, \mathrm{pH}$ 7.5). Sebanyak $2 \mu \mathrm{L}$ suspensi tanaman diteteskan ke atas membran nitroselulosa. Setelah tetesan sampel kering, membran direndam di dalam $10 \mathrm{~mL}$ larutan blocking non-fat milk $2 \%$ dalam TBS yang mengandung Triton X-100 dengan konsentrasi akhir 2\%. Membran diinkubasi pada suhu ruang sambil digoyang menggunakan EYELA multi shaker dengan kecepatan $50 \mathrm{rpm}$ selama 1 jam. Membran selanjutnya dicuci 5 kali dengan $\mathrm{dH}_{2} \mathrm{O}$, tiap pencucian berlangsung 5 menit sambil digoyang dengan kecepatan $100 \mathrm{rpm}$.

Membran nitroselulosa direndam dalam $2.5 \mathrm{~mL}$ TBS yang mengandung $1 \mu \mathrm{L}$ antibodi pertama ditambah non-fat milk dengan konsentrasi akhir 2\%, dan diinkubasi selama semalam pada suhu $4{ }^{0} \mathrm{C}$. Membran dicuci kembali dengan Tween $0.05 \%$ dalam TBS (TBST) sebanyak 5 kali sambil digoyang dengan kecepatan 100 rpm, masing-masing selama 5 menit.

Membran nitroselulosa direndam dalam $2.5 \mathrm{~mL}$ TBS yang mengandung $1 \mu \mathrm{L}$ antibodi kedua (konjugat) ditambah non-fat milk dengan konsentrasi akhir 2\%, kemudian diinkubasi selama 2 jam sambil digoyang dengan kecepatan $50 \mathrm{rpm}$. Membran dicuci kembali dengan TBST sebanyak 5 kali sambil digoyang dengan kecepatan $100 \mathrm{rpm}$.

Tahap terakhir, membran direndam dalam $10 \mathrm{~mL}$ bufer AP (Tris-HCl $0.1 \mathrm{M}, \mathrm{NaCl}$ $0.1 \mathrm{M}, \mathrm{MgCl}_{2} 5 \mathrm{mM}, \quad \mathrm{pH}$ 9.5) yang mengandung 1 tablet nitro blue tetrazolium (NBT) dan bromo chloro indolil phosphate (BCIP) untuk pewarnaan. Reaksi positif apabila terjadi perubahan warna putih menjadi ungu pada membran nitroselulosa yang telah ditetesi cairan tanaman dan reaksi dapat dihentikan dengan merendam membran dalam $\mathrm{dH}_{2} \mathrm{O}$. Reaksi positif ditandai terbentuknya warna ungu pada membran nitroselulosa. Insidensi penyakit yang disebabkan oleh Begomovirus dihitung dengan menggunakan rumus:

$\mathrm{IP}=\Sigma \frac{\text { jumlah tanaman yang terinfeksi virus }}{\text { jumlah tanaman yang dideteksi }} \times 100 \%$

\section{Identifikasi Begomovirus melalui Teknik PCR}

DNA total diekstraksi dari tanaman mentimun terinfeksi Begomovirus menggunakan metode Doyle dan Doyle (1987). Hasil ekstraksi berupa DNA total diamplifikasi dengan PCR menggunakan primer universal gen protein selubung pAV494/pAC1048 dengan amplikon berukuran $\pm 550 \mathrm{pb}$ (Wyatt dan Brown, 1996). Visualisasi produk PCR dilakukan dengan elektroforesis menggunakan gel agarosa $1.5 \%$.

\section{Perunutan dan Analisis DNA Begomovirus}

Perunutan nukleotida hasil PCR dilakukan di First Base, Malaysia. Hasil sekuen dianalisis menggunakan Basic Local Alignment Tool (BLAST) dan ClustalW multiple alignment dengan BioEdit V7.05. Analisis filogenetika menggunakan Molecular Evolutionary Genetics Analysis (MEGA 6) (Tamura et al., 2013).

\section{HASIL DAN PEMBAHASAN}

\section{Penyakit Kuning pada Tanaman Mentimun di Jawa Barat dan Bali}

Survei pada pertanaman mentimun di Jawa Barat dan Bali menunjukkan adanya 
variasi gejala penyakit yang disebabkan oleh Begomovirus. Gejala yang umum ditemukan antara lain mosaik kuning pada lamina daun disertai penebalan tulang daun (vein banding) (Gambar 1). Adanya variasi gejala infeksi Begomovirus di lapangan dipengaruhi oleh varietas mentimun yang berbeda pada saat pengamatan. Mentimun varietas Sabana yang ditanam di Sumedang menunjukkan gejala mosaik kuning dan vein banding, sedangkan varietas Bandana di Karawang didominasi oleh gejala klorosis, mosaik kuning, dan vein banding. Mentimun varietas Vanessa di Sukabumi menunjukkan gejala mosaik hijau muda, dan tepian daun yang menggulung ke atas (cupping) (Gambar 1).

Gejala pada pertanaman mentimun di Bali sedikit berbeda dengan yang ditemukan di Jawa Barat. Pertanaman mentimun jepang di Tabanan dan Gianyar didominasi gejala daun menguning, penebalan tulang daun, dan tanaman menjadi kerdil, sedangkan gejala yang teramati di Klungkung yaitu gejala mosaik hijau pada lamina daun, tepian daun melengkung ke atas, dan penebalan tulang daun. Wiratama et al. (2015) menyatakan bahwa gejala penyakit pada pertanaman mentimun di Bali berasosiasi dengan infeksi SLCCNV. Gejala paling parah ditemukan di Tabanan, yaitu tanaman menjadi kerdil dan tidak menghasilkan buah sama sekali. Menurut Flock dan Mayhew (1981), Squash leaf curl virus (SLCV) yang menginfeksi labu pada saat persemaian akan menyebabkan kematian, dan apabila menginfeksi pada fase vegetatif maka akan menyebabkan tanaman kerdil, daun keriting, tulang daun menjadi lebih tebal, dan proses pembungaan akan menjadi terhambat.

Infeksi ToLCNDV dan SLCCNV dapat terjadi secara tunggal maupun ganda di lapangan dengan gejala yang hampir sama. Gejala infeksi SLCV pada beberapa tanaman Cucurbitaceae diantaranya yaitu daun mosaik kuning, penebalan tulang daun, daun keriting, berkurangnya area lamina daun, dan mengalami malformasi (Singh et al., 2008; Tahir et al., 2010). ToLCNDV dapat menginfeksi tanaman Cucurbitaceae, Solanaceae, dan gulma. Gejala umum yang ditimbulkan oleh ToLCNDV antara lain daun mosaik kuning, keriting, penebalan tulang daun, malformasi sehingga menyebabkan hasil produksi menurun (Tiwari et al., 2010; Pratap et al., 2011). Variasi gejala infeksi Begomovirus pada mentimun di lapangan dapat disebabkan adanya infeksi campuran dua virus atau lebih. Infeksi tunggal SLCV pada tanaman melon menyebabkan gejala klorosis ringan dan sedikit keriting, sedangkan infeksi yang disebabkan oleh Watermelon chlorotic spot virus (WmCSV) berupa klorosis dengan bercak kuning. Infeksi ganda SLCV dan WmCSV menyebabkan gejala mosaik kuning disertai penebalan tulang daun, dan tanaman menjadi kerdil. Infeksi ganda juga menghambat pembentukan "netting" pada buah, perubahan bentuk buah, dan menyebabkan penurunan hasil mencapai $80 \%$ (Ringwald dan Lapidot, 2011).

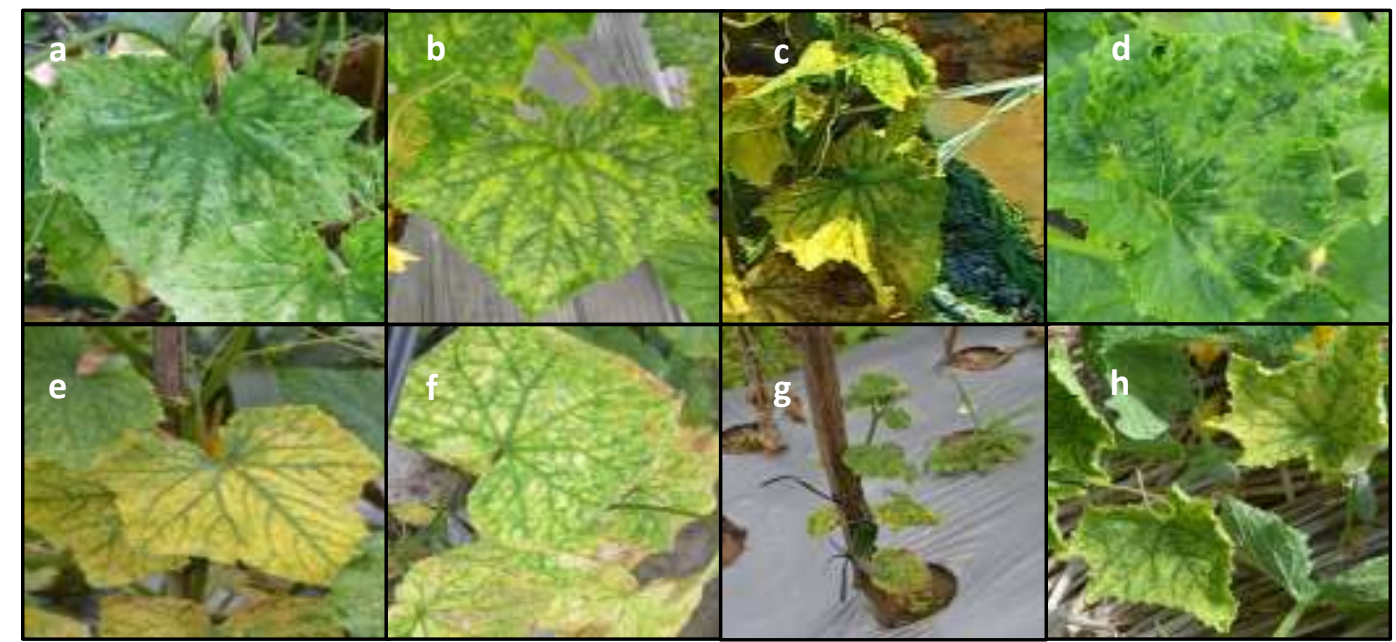

Gambar 1. Variasi gejala penyakit kuning yang ditemukan di lapang. (a) mosaik hijau, (b) klorosis, (c) vein banding, (d) rugose, (e) kuning dan vein banding, (f) mosaik kuning, (g) kerdil, (h) mosaik hijau dan cupping. 
Infeksi ganda antara SLCCNV dan Loofa yellow mosaic virus (LYMV) berasosiasi dengan penyakit mosaik pada tanaman Cucurbitaceae di Vietnam menyebabkan mosaik kuning dan tanaman kerdil (Revill et al., 2003).

Laporan mengenai infeksi ganda antara ToLCNDV dan SLCCNV pada tanaman Cucurbitaceae masih sedikit. Penyakit mosaik kuning pada tanaman labu di India diketahui disebabkan oleh dua virus yang berbeda, yaitu ToLCNDV di daerah India bagian selatan dan SLCCNV di India bagian utara (Maruthi et al., 2007). Gejala infeksi antara ToLCNDV dan SLCCNV yang ditemukan di Jawa Barat dan Bali sulit untuk dibedakan, maka diperlukan deteksi serologi atau asam nukleat untuk memastikan virus penyebabnya.

Hasil deteksi DIBA menunjukkan infeksi ToLCNDV mendominasi semua lokasi pengamatan (Tabel 1). Insidensi penyakit oleh ToLCNDV berkisar 50\% sampai dengan $100 \%$, kecuali di Sukabumi sebesar $28 \%$. Infeksi SLCV ditemukan di semua pertanaman mentimun di Bali. Insidensi penyakit paling tinggi ditemukan di Kabupaten Tabanan $(80 \%)$, sedangkan paling rendah ditemukan di Gianyar (42\%).

Infeksi SLCV di India menyebabkan insidensi penyakit pada tanaman labu sebesar 45\%-100\%. Insidensi penyakit yang tinggi ini dipengaruhi oleh penggunaan benih hibrida sepanjang musim tanam dan budidaya tanaman monokultur (Maruthi et al., 2007). Variasi gejala pada berbagai varietas mentimun di Jawa Barat dan Bali mengindikasikan adanya infeksi campuran dengan virus lainnya. Infeksi campuran akan menghasilkan penyakit yang lebih kompleks, salah satunya ditunjukkan dengan gejala yang lebih parah dibandingkan infeksi tunggal. Infeksi ganda antara ToLCNDV dan SLCV terdeteksi pada semua sampel Bali, berkisar antara $32 \%$ sampai dengan $64 \%$, dan juga di Sumedang serta Karawang sebesar 52\% dan $28 \%$.

Interaksi antar virus dalam suatu infeksi campuran dapat bersifat sinergis, antagonis, maupun aditif berdasarkan ekspresi gejala, ekspresi gen, replikasi, dan pergerakan virus di dalam sel maupun ke seluruh bagian tumbuhan. Konsentrasi virus Pepper huasteco virus (PHV) dan Pepper golden mosaic virus (PGMV) pada $N$. benthamiana meningkat pada saat infeksi campuran menunjukkan kedua virus tersebut berinteraksi secara sinergis dalam proses replikasi virus (MendezLozano et al., 2002). Interaksi sinergis juga terjadi antara African cassava mosaic virus (ACMV) dan East African cassava mosaic virus (EACMV) pada tanaman ubi kayu ditandai gejala mosaik, keriting, dan malformasi pada daun yang lebih parah bila dibandingkan dengan infeksi tunggal ACMV/EACMV.

Tabel 1. Insidensi penyakit oleh Begomovirus berdasarkan deteksi serologi DIBA

\begin{tabular}{|c|c|c|c|c|}
\hline \multirow{2}{*}{ Lokasi1 $^{1)}$} & \multirow{2}{*}{ Varietas } & \multicolumn{3}{|c|}{ Insidensi penyakit $(\%)^{2)}$} \\
\hline & & ToLCNDV & SLCV & ToLCNDV + SLCV \\
\hline Sumedang- 1 & Sabana & $41 / 50(82)$ & $0 / 50(0)$ & $0 / 50(0)$ \\
\hline 2 & Sabana & $40 / 50(80)$ & $28 / 50(56)$ & $26 / 50(52)$ \\
\hline Sukabumi- 1 & Vanessa & $25 / 50(50)$ & $0 / 50(0)$ & $0 / 50(0)$ \\
\hline 2 & Bandana/Wulan & $14 / 50(28)$ & $0 / 50(0)$ & $0 / 50(0)$ \\
\hline Karawang- 1 & Bandana & $48 / 50(96)$ & $15 / 50(30)$ & $14 / 50(28)$ \\
\hline 2 & Bandana & $38 / 50(78)$ & $0 / 50(0)$ & $0 / 50(0)$ \\
\hline Tabanan -1 & Spring Swallow & $35 / 50(70)$ & $37 / 50(74)$ & $28 / 50(56)$ \\
\hline 2 & Roberto & $35 / 50(70)$ & $40 / 50(80)$ & $27 / 50(54)$ \\
\hline Gianyar & Sema & $43 / 50(86)$ & $21 / 50(42)$ & $21 / 50(42)$ \\
\hline Klungkung- 1 & Lokal & $34 / 50(68)$ & $23 / 50(46)$ & $16 / 50(32)$ \\
\hline 2 & Lokal & $50 / 50(100)$ & $32 / 50(64)$ & $32 / 50(64)$ \\
\hline
\end{tabular}

Keterangan: ${ }^{1)}$ Karawang-1= lahan 1 di Kecamatan Karawang Barat, Karawang-2= lahan 2 di Kecamatan Karawang Barat; Sumedang-1= lahan 1 di Kecamatan Ujung Jaya, Sumedang-2= lahan 2 di Kecamatan Ujung Jaya; Sukabumi-1= lahan 1 di Kecamatan Cibadak, Sukabumi-2= lahan 2 di Kecamatan Parung Kuda; Klungkung-1= lahan 1 di Kecamatan Klungkung, Klungkung-2= lahan 2 di Kecamatan Klungkung, Tabanan-1= lahan 1 di Kecamatan Baturiti, Tabanan-2= lahan 2 di Kecamatan Baturiti; Gianyar= lahan di Kecamatan Puyangan.

${ }^{2)}$ Insidensi penyakit $=\mathrm{n} / \mathrm{N} \times 100 \%, \mathrm{n}=$ jumlah tanaman positif terdeteksi virus, $\mathrm{N}=$ total tanaman yang diuji. Angka dalam kurung menyatakan persentase insidensi penyakit. 
Peningkatan konsentrasi ACMV pada fase awal infeksi dan EACMV pada fase akhir infeksi menunjukkan interaksi sinergis akibat infeksi ganda ACMV dan EACMV (Fondong et al., 2000). Infeksi campuran antar Begomovirus dapat menyebabkan proses rekombinasi sehingga menghasilkan strain atau bahkan spesies baru yang lebih ganas pada lingkungan tertentu (Mendez-Lozano et al., 2003). Keberadaan SLCCNV pada pertanaman mentimun di Jawa Barat dan infeksi ganda antara ToLCNDV dan SLCCNV di Jawa Barat dan Bali merupakan temuan baru dari penelitian ini.

\section{Identifikasi Begomovirus pada Tanaman Mentimun dengan Teknik PCR}

\section{a. Deteksi Menggunakan Primer Universal pAv494 dan pAc1048}

Deteksi Begomovirus yang menginfeksi tanaman mentimun dengan PCR berhasil mengamplifikasi DNA semua isolat yang mewakili setiap lokasi pengambilan sampel yaitu isolat SM (Sumedang), SK (Sukabumi), K (Karawang), KA (Klungkung), TA (Tabanan), dan G (Gianyar). Amplikon gen protein selubung Begomovirus yang dihasilkan berukuran $\sim 550 \mathrm{pb}$ (Gambar 2). Gen protein selubung Begomovirus merupakan daerah yang sangat conserved dalam genom Begomovirus, sehingga dapat digunakan untuk identifikasi dari Begomovirus. Gen protein selubung berperan dalam proses enkapsidasi partikel virus, penularan melalui serangga vektor, dan diduga terlibat dalam pergerakan virus di dalam tumbuhan (Brown et al., 2012).

\section{b. Perunutan dan Analisis DNA Begomovirus}

Hasil BLAST nukleotida isolat Begomovirus dari Jawa Barat dan Bali menunjukkan terdapat tiga spesies Begomovirus yang berhasil teridentifikasi, yaitu SLCCNV, ToLCNDV, dan Ageratum yellows vein virus (AYVV). Menurut Brown et al. (2012), suatu isolat virus dinyatakan satu spesies Begomovirus yang sama apabila memiliki kesamaan nukleotida lebih dari $89 \%$. Hasil perunutan nukleotida menunjukkan bahwa isolat asal Tabanan (TA) termasuk ke dalam spesies SLCCNV, isolat asal Sumedang (SM), Karawang (K), Sukabumi (SK), dan Klungkung (KA) termasuk ke dalam spesies
ToLCNDV, sedangkan isolat asal Gianyar (G) termasuk ke dalam spesies AYVV. Hasil perunutan nukleotida ini mengkonfirmasi hasil deteksi serologi DIBA bahwa ToLCNDV dan SLCCNV merupakan Begomovirus yang menginfeksi tanaman mentimun di Jawa Barat dan Bali. Adapun isolat virus asal Gianyar yang teridentifikasi sebagai AYVV sangat mungkin terjadi. Antiserum AYVV belum tersedia untuk deteksi serologi, tanaman gulma sebagai tanaman inang utama AYVV banyak ditemukan di sekitar lahan pengambilan sampel di Bali.

SLCCNV isolat Tabanan, Bali memiliki persentase kesamaan nukleotida tertinggi (94.5\%) dengan isolat SLCCNV asal Malaysia (Tabel 2). Analisis kesamaan nukleotida ini sesuai dengan laporan Wiratama et al. (2015), bahwa SLCCNV isolat Indonesia memiliki kedekatan dengan isolat SLCCNV asal Malaysia berdasarkan hasil amplifikasi gen TrAp dan Rep sebesar 91\%. SLCCNV isolat Tabanan memiliki similaritas kurang dari $89 \%$ dengan dua isolat Begomovirus yang menginfeksi cabai sebagai outgroup yaitu Tomato leaf curl Kanchanaburi virus (TLCKV) dan Pepper yellow leaf curl Indonesia virus (PYLCIV).

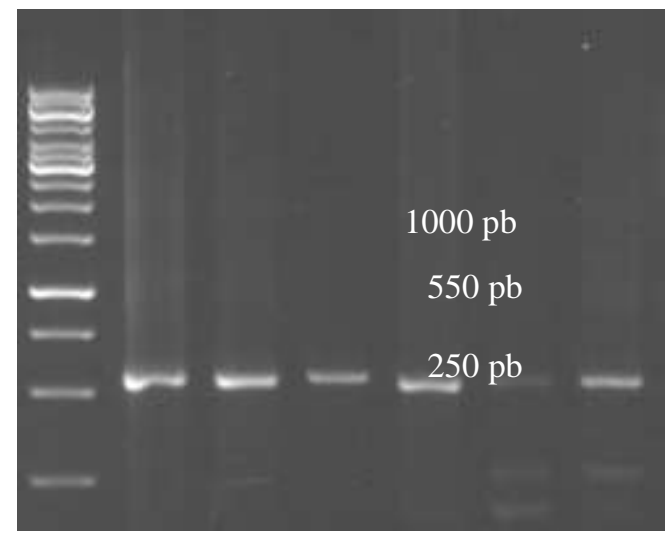

Gambar 2. Hasil amplifikasi gen protein selubung Begomovirus menggunakan primer universal pAv494 dan pAc1048. Lajur $\mathrm{M}=$ marker $1 \mathrm{~kb}$ DNA ladder; $\mathrm{SM}=$ isolat asal Sumedang; $\mathrm{SK}=$ isolat asal Sukabumi; $\mathrm{K}=$ isolat asal Karawang; $\mathrm{KA}=$ isolat asal Klungkung; $\mathrm{TA}=$ isolat asal Tabanan; $\mathrm{G}=$ isolat asal Gianyar. 
Tabel 2. Kesamaan SLCCNV isolat Tabanan dengan isolat yang terdapat di GenBank

\begin{tabular}{|c|c|c|c|c|}
\hline \multirow{2}{*}{ Isolat } & \multicolumn{2}{|c|}{ Protein selubung $(\%)^{1)}$} & \multirow{2}{*}{ Tanaman inang } & \multirow{2}{*}{ Nomor aksesi } \\
\hline & $\mathrm{nt}$ & aa & & \\
\hline SLCCNV-MAS & 94.5 & 95.8 & Cucumis sativus & EF197940 \\
\hline SLCCNV-PHI & 92.4 & 96.3 & Sechium edule & EU487031 \\
\hline SLCCNV-THA & 91.9 & 94.7 & Benincasa hispida & EU543562 \\
\hline SLCCNV-VIE & 93.0 & 94.2 & Cucurbita moschata & КС857509 \\
\hline SLCCNV-CHN & 92.1 & 94.7 & C. moschata & KC171648 \\
\hline SLCCNV-PAK & 89.5 & 95.8 & С. реро & AM286794 \\
\hline SLCCNV-IND & 89.8 & 96.8 & C. moschata & DQ026296 \\
\hline TLCKV & 76.9 & 76.9 & Capsicum aпnит & KF446675 \\
\hline PYLCIV & 77.4 & 77.4 & Capsicum annum & NC008283 \\
\hline
\end{tabular}

Keterangan: ${ }^{1)}$ Persentase tingkat kesamaan isolat virus didapatkan dari perhitungan menggunakan BioEdit v7.0.5. $\mathrm{nt}=$ nukleotida, $\mathrm{aa}=$ asam amino

Berdasarkan hasil BLAST pada GenBank, isolat Klungkung, Karawang, Sukabumi, dan Sumedang memiliki kesamaan nukleotida dan asam amino tertinggi dengan isolat ToLCNDV asal Klaten, Indonesia (AB613825) (Tabel 3). ToLCNDV isolat KA, $\mathrm{K}$, SK, dan SM memiliki kesamaan nukleotida yang rendah dengan dua isolat Begomovirus yang diketahui menginfeksi tanaman cabai di
Indonesia yaitu TLCKV dan PYLCIV berkisar $67.5 \%$ sampai dengan $78.5 \%$. Kesamaan nukleotida antar ToLCNDV isolat Klungkung, Karawang, Sukabumi, Sumedang, dan Klaten (AB613825) sangat tinggi mencapai 96\%99.8\%. Hal ini menunjukkan keragaman gen protein selubung ToLCNDV asal Indonesia tidak dipengaruhi oleh faktor geografis.

Tabel 3. Kesamaan nukleotida dan asam amino ToLCNDV isolat Sumedang, Karawang, Sukabumi, dan Klungkung dengan ToLCNDV isolat lainnya yang terdaftar pada GenBank

\begin{tabular}{|c|c|c|c|c|c|c|c|c|c|}
\hline \multirow{2}{*}{ Isolat ${ }^{1)}$} & \multicolumn{2}{|c|}{ Klungkung } & \multicolumn{2}{|c|}{ Karawang } & \multicolumn{2}{|c|}{ Sukabumi } & \multicolumn{2}{|c|}{ Sumedang } & \multirow{2}{*}{ Nomor aksesi } \\
\hline & nt & aa & $\mathrm{nt}$ & aa & $\mathrm{nt}$ & aa & nt & aa & \\
\hline ToLCNDV-IDN & 97.3 & 99.4 & 97.0 & 99.4 & 96.3 & 97.9 & 97.2 & 99.4 & AB613825 \\
\hline ToLCNDV-THA1 & 94.2 & 98.9 & 94.7 & 98.9 & 94.0 & 97.3 & 94.9 & 98.9 & AB368448 \\
\hline THA2 & 94.2 & 98.9 & 94.7 & 98.9 & 94.0 & 97.3 & 94.9 & 98.9 & AB330079 \\
\hline ToLCNDV-IND1 & 94.2 & 98.9 & 94.4 & 98.9 & 93.7 & 97.3 & 94.4 & 98.9 & KM269350 \\
\hline IND2 & 94.0 & 98.9 & 94.0 & 98.9 & 93.3 & 96.8 & 94.2 & 98.9 & KJ744258 \\
\hline IND3 & 93.8 & 98.9 & 93.8 & 98.9 & 93.1 & 97.3 & 94.0 & 98.9 & FN645905 \\
\hline IND4 & 93.5 & 98.4 & 93.8 & 98.4 & 93.1 & 96.8 & 94.0 & 98.4 & AM286433 \\
\hline IND5 & 93.1 & 98.9 & 93.5 & 98.9 & 92.8 & 97.3 & 93.7 & 98.9 & KC207815 \\
\hline ToLCNDV-PAK1 & 94.4 & 98.9 & 94.4 & 98.9 & 93.7 & 97.3 & 94.5 & 98.9 & KC914896 \\
\hline PAK2 & 94.0 & 97.9 & 94.0 & 97.9 & 93.3 & 96.3 & 94.2 & 97.9 & DQ116885 \\
\hline ToLCNDV-TAI & 93.3 & 98.4 & 93.7 & 98.4 & 93.1 & 96.8 & 93.7 & 98.4 & GU180095 \\
\hline TLCKV & 68.4 & 78.0 & 68.5 & 78.0 & 67.5 & 75.9 & 68.7 & 78.0 & KF446675 \\
\hline PYLCIV & 71.0 & 78.5 & 71.2 & 78.5 & 70.5 & 76.9 & 71.3 & 78.5 & NC008283 \\
\hline $\begin{aligned} & \text { Keterangan: }{ }^{1)} \text { ToLCN } \\
& \text { ToLCN } \\
& \text { Thailan } \\
& \text { mengin } \\
& \text { Momor } \\
& \text { sicerari } \\
& \text { IND5, } \\
& \text { ToLCN } \\
& \text { asal Tai } \\
& \text { virus as } \\
& \text { virus as } \\
& \text { 2) } \text { Persenta }\end{aligned}$ & $\begin{array}{l}\text { N, T } \\
\text { asal T } \\
\text { ig me } \\
\text { Citrul } \\
\text { haran } \\
\text { LCND } \\
\text { ToLC } \\
\text { sal Pal } \\
\text { yang } \\
\text { lonesia } \\
\text { onesia } \\
\text { gkat k }\end{array}$ & $\begin{array}{l}\text { ToL } \\
\text { ND4 } \\
\text { DV a } \\
\text { an ya } \\
\text { ginfe }\end{array}$ & $\begin{array}{l}\text { DV-I } \\
\text { olat T } \\
\text { Indic } \\
\text { meng } \\
\text { C. me } \\
\text { sinfek } \\
\text { infek } \\
\text { lat vi }\end{array}$ & $\begin{array}{l}\text { 3, iso } \\
\text { CND } \\
\text { ang } \\
\text { eksi } \\
\text { var. } n \\
\text { C. an } \\
\text {. ann } \\
\text { didap }\end{array}$ & $\begin{array}{l}\text { ToL } \\
\text { tsal In } \\
\text { nginfe } \\
\text { enopo } \\
\text { kuwa; } \\
m ; \mathrm{PY} \\
\text { kan da }\end{array}$ & $\begin{array}{l}\text { DV a } \\
\text { yang } \\
\text { Luff } \\
n \text { alb } \\
\text { CKV } \\
\text { IV, is }\end{array}$ & $\begin{array}{l}\text { C. sat } \\
\text { NDV- } \\
\text { solat } \\
\text { NDV } \\
\text { India } \\
\text { enginf } \\
\text { cylind } \\
\text {; ToLe } \\
\text { olat } T \\
\text { t Pep }\end{array}$ & $\begin{array}{l}\text { ang } \\
\text { si } C . n \\
\text { al; To } \\
\text { JDV-T } \\
\text { ato le } \\
r \text { yello }\end{array}$ & $\begin{array}{l}\text { NDV-TH1, isolat } \\
\text { ToLCNDV asal } \\
\text { asal India yang } \\
\text { yang menginfeksi } \\
\text { sinfeksi Lagenaria } \\
\text { chata; ToLCNDV- } \\
\text { iNDV-PK1, isolat } \\
\text { isolat ToLCNDV } \\
\text { curl Kanchanaburi } \\
\text { eaf curl Indonesia } \\
\text { BioEdit v7.0.5. nt= }\end{array}$ \\
\hline
\end{tabular}


Analisis nukleotida menunjukkan bahwa isolat Gianyar, Bali memiliki kesamaan nukleotida tertinggi (92.1\%) dengan Ageratum yellows vein virus asal Indonesia yang menginfeksi tanaman $N$. benthamiana. Namun, AYVV isolat Bali memiliki kesamaan asam amino tertinggi (95.8\%) dengan AYVV yang menginfeksi tomat Amerika serikat sebesar 95.8\% (Tabel 4).

\section{Analisis Filogenetika}

Analisis filogenetika menunjukkan bahwa isolat SLCCNV Bali mengelompok dengan isolat SLCCNV asal Malaysia, Filipina, Thailand, Vietnam, dan Cina, dan terpisah dengan isolat SLCCNV asal India dan Pakistan (Gambar 3).

Menurut Tahir et al. (2010), SLCCNV dibedakan menjadi dua strain virus berdasarkan lokasi geografis yaitu strain
"India" dan "Cina". SLCCNV strain "India" diketahui hanya menyebar di wilayah India dan Pakistan, sedangkan strain "Cina" ditemukan di Cina dan Vietnam (Revill et al., 2003; Tahir et al., 2010). Berdasarkan analisis filogenetika, SLCCNV isolat Bali termasuk ke dalam strain "Cina".

Hasil analisis filogenetika ToLCNDV menunjukkan bahwa isolat Sukabumi, Karawang, Sumedang, dan Klungkung membentuk satu cluster dengan ToLCNDV isolat Klaten, Indonesia dan terpisah dengan ToLCNDV isolat dari Negara lainnya (Gambar 4). ToLCNDV isolat Tegal, Sleman, Sukaharjo, dan Bogor memiliki kesamaan nukleotida yang tinggi sebesar lebih dari $95 \%$ dengan isolat ToLCNDV asal Klaten, dan diklasifikasikan sebagai strain "Indonesia" (Mizutani et al., 2011; Septariani et al., 2014).

Tabel 4. Kesamaan nukleotida dan asam amino AYVV isolat Gianyar dengan isolat yang terdapat di GenBank

\begin{tabular}{|c|c|c|c|c|}
\hline \multirow{2}{*}{ Isolat } & \multicolumn{2}{|c|}{ Protein selubung (\%) ${ }^{1)}$} & \multirow{2}{*}{ Tanaman inang } & \multirow{2}{*}{ Nomor aksesi } \\
\hline & $\mathrm{nt}$ & aa & & \\
\hline AYVV-IND & 92.1 & 95.2 & Nicotiana benthamiana & AB100305 \\
\hline AYVV-PHI & 91.6 & 95.2 & Synedrella nodiflora & KC577539 \\
\hline AYVV-CHN & 90.9 & 95.2 & Sonchus oleraceus & AM940137 \\
\hline AYVV-USA & 91.2 & 95.8 & Solanum lycopersicum & KR094067 \\
\hline AYVV-THA & 90.2 & 94.7 & Sauropus androgynous & JN809820 \\
\hline AYVV-TAI & 89.5 & 95.2 & N. tabacum & EF458639 \\
\hline AYVV-CHN & 90.6 & 95.2 & Ageratum conyzoides & KJ016235 \\
\hline TLCKV & 74.5 & 80.6 & Capsicum annum & KF446675 \\
\hline PYLCIV & 72.4 & 79.5 & C. annum & NC008283 \\
\hline
\end{tabular}

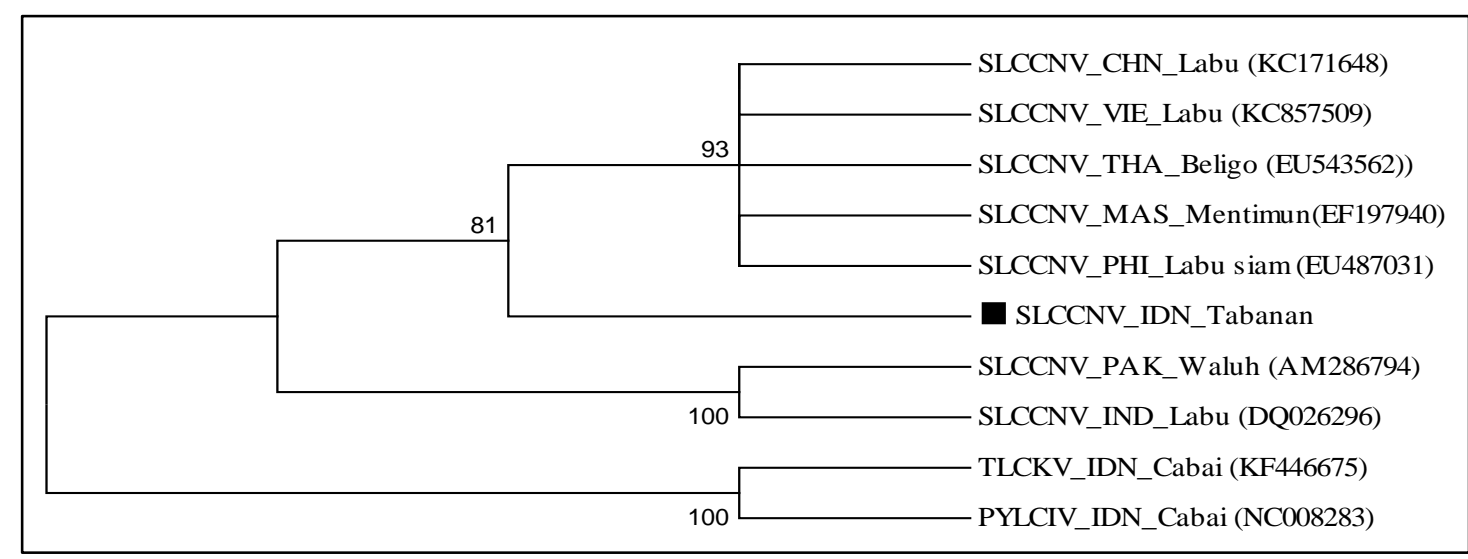

Gambar 3. Pohon filogenetika Squash leaf curl China virus yang menginfeksi tanaman mentimun di Bali menggunakan perangkat MEGA 6.0 dengan metode Neighbour Joining dengan bootstrap 1000x. 


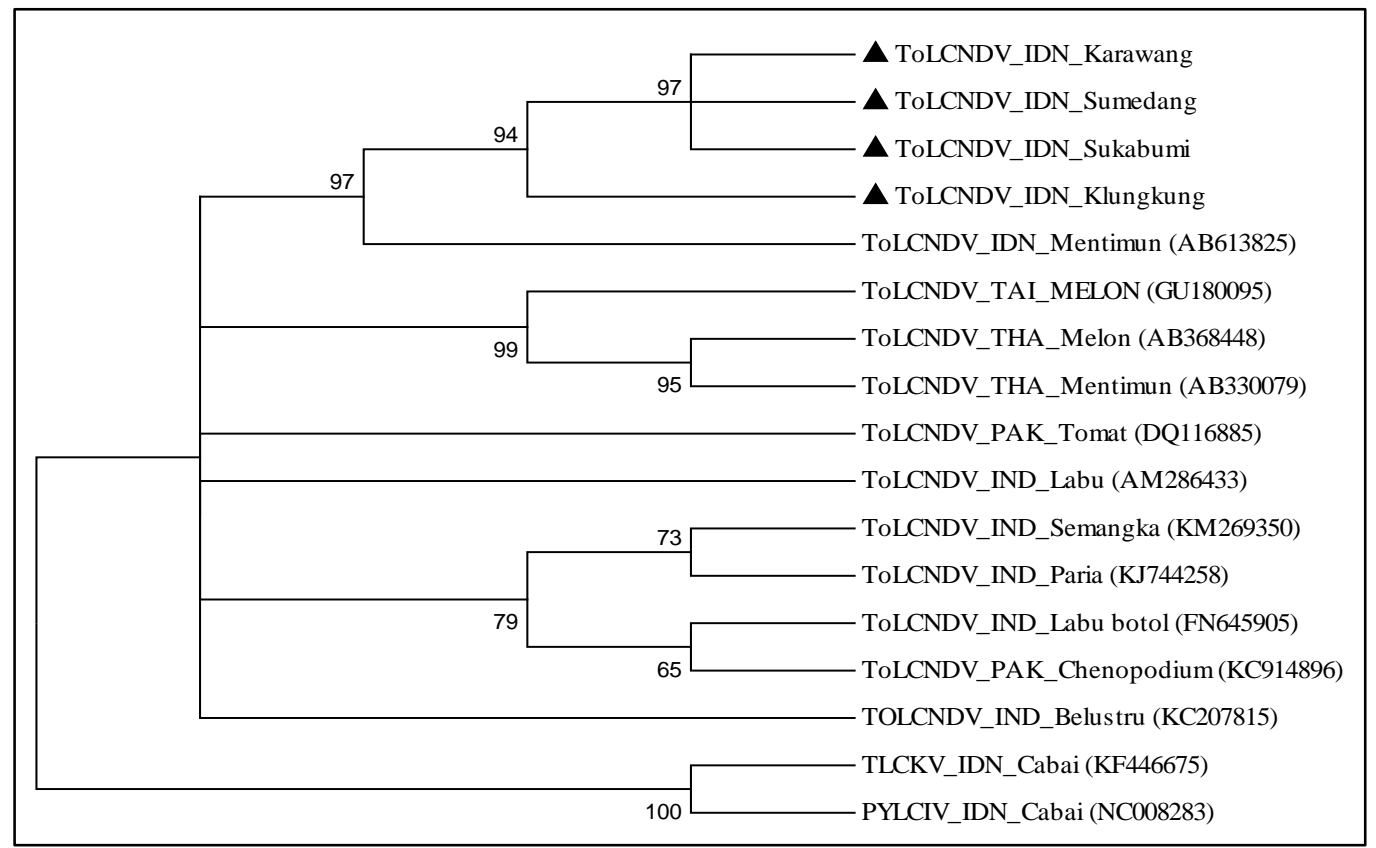

Gambar 4. Pohon filogenetika ToLCNDV yang menginfeksi tanaman mentimun di Jawa Barat dan Bali menggunakan perangkat MEGA 6.0 dengan metode Neighbour Joining dengan bootstrap 1000x.

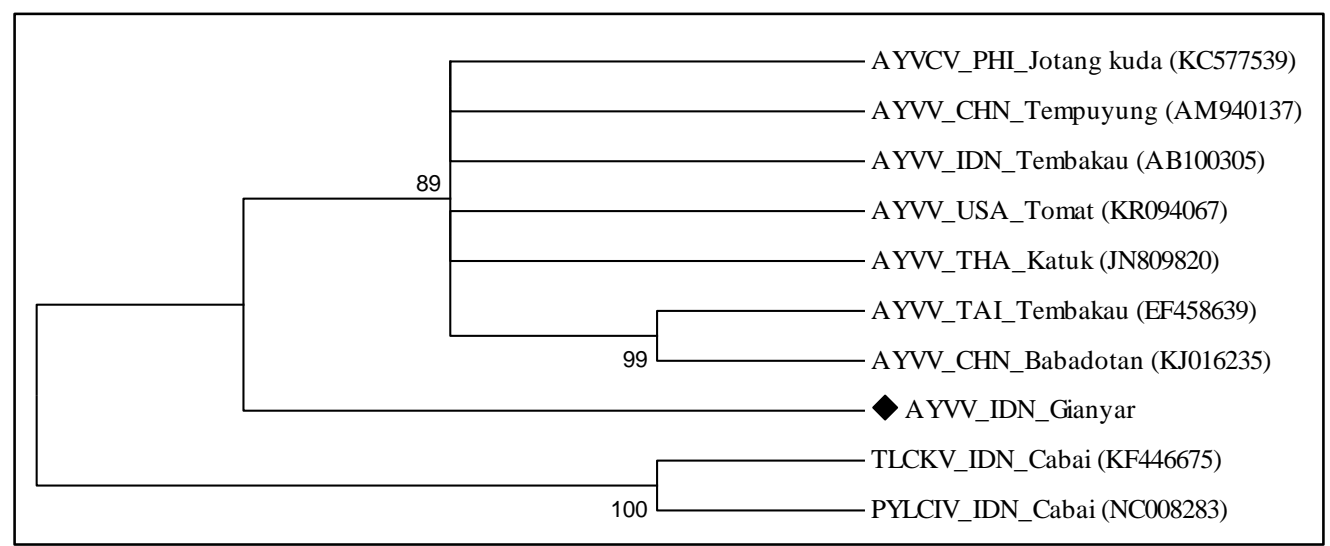

Gambar 5. Pohon filogenetika AYVV yang menginfeksi tanaman mentimun di Bali menggunakan perangkat MEGA 6.0 dengan metode Neighbour Joining dengan bootstrap 1000x.

AYVV merupakan salah satu spesies Begomovirus yang menginfeksi tanaman gulma Ageratum conyzoides. Isolat AYVV Bali memiliki kekerabatan yang cukup jauh dengan AYVV isolat Indonesia yang menginfeksi $N$. benthamiana meskipun hasil kesejajaran nukleotida dan asam amino cukup tinggi. Hasil pengamatan yang dilakukan pada lahan mentimun di Bali menunjukkan adanya beberapa jenis gulma yang tumbuh di sekitar tanaman utama, salah satunya $A$. conyzoides yang menguning. Diduga gulma tersebut sebagai tanaman reservoir AYVV pada pertanaman mentimun. AYVV memang belum pernah dilaporkan menginfeksi secara alami pada tanaman mentimun di Indonesia. Namun, keberadaan gulma yang merupakan tanaman inang utama dari AYVV banyak ditemukan di pada lahan pertanaman mentimun di Bali. Diduga, AYVV yang ada pada gulma $A$. conyzoides diakuisisi oleh $B$. tabaci kemudian terbawa secara alami pada saat serangga makan pada tanaman mentimun.

Penyakit kuning pada tanaman mentimun di Jawa Barat dan Bali disebabkan oleh dua spesies Begomovirus yaitu Tomato leaf curl New Delhi virus dan Squash leaf curl China virus. ToLCNDV merupakan Begomovirus yang 
mendominasi pertanaman mentimun di provinsi Jawa Barat, Jawa Tengah, D.I Yogyakarta, dan Bali dengan insidensi penyakit 28-100\% (Septariani et al., 2014). SLCCNV pertama kali dilaporkan pada pertanaman mentimun di Bali, dan saat ini diketahui keberadaannya di Kabupaten Karawang dan Sumedang (Jawa Barat). ToLCNDV dan SLCCNV ditularkan secara efektif melalui kutukebul Bemisia tabaci (Hemiptera: Aleyrodidae) secara persisten sirkulatif nonpropagatif. Peningkatan insidensi Begomovirus berasosiasi dengan ledakan populasi $B$. tabaci sebagai serangga vektor, terutama $B$. tabaci biotipe B dan Q (Maruthi et al., 2007).

ToLCNDV merupakan masalah penting pada tanaman hortikultura di Asia (Maruthi et al., 2007; Mizutani et al., 2011; Pratap et al., 2011). Virus ini memiliki kisaran inang yang sangat luas dan telah diketahui terdapat 23 isolat yang dilaporkan dari tanaman inang yang berbeda (Padidam et al., 1995; Tiwari et al., 2010). SLCCNV memiliki karakter biologi dan molekuler yang mirip dengan ToLCNDV (Brown et al., 2012). Selain Cucurbitaceae, SLCCNV juga dilaporkan mampu menginfeksi secara alami pada tanaman Chenopodium murale, Convolvulus sp., Prosporis farcta, Malva parviflora (Al-Musa et al., 2008). Tanaman gulma dikenal sebagai tanaman reservoir dan berperan dalam epidemiologi penyakit yang disebabkan oleh Begomovirus. Gulma berperan dalam menjaga keberadaan virus beserta serangga vektornya tetap hidup dan menyebabkan outbreak pada musim tanam selanjutnya. A. conyzoides dikenal sebagai inang alami Begomovirus. Gulma ini banyak ditemukan pada berbagai pertanaman hortikultura dan umumnya menunjukkan gejala pemucatan tulang daun dan mosaik kuning (Khan et al., 2014). Meskipun Ageratum yellow vein virus yang menginfeksi pertanaman mentimun di Gianyar bukan menjadi masalah utama, namun hal ini perlu perhatian lebih lanjut. Infeksi lebih dari dua spesies Begomovirus akan menyebabkan gejala yang lebih parah.

Infeksi ganda antara ToLCNDV dan SLCCNV pada pertanaman mentimun di Jawa Barat dan Bali merupakan temuan pertama pada penelitian ini. Kedua Begomovirus tersebut memiliki karakteristik biologis dan molekuler yang mirip. Hal ini dapat menyebabkan terjadinya rekombinasi dan berpotensi menghasilkan strain baru yang lebih ganas (Fondong et al., 2000). Faktor utama yang berperan dalam munculnya spesies baru dan penyebarannya antara lain adanya evolusi keragaman virus, perubahan sistem dan intensitas budidaya tanaman, perubahan biologi serangga vektor, introduksi tanaman baru, introduksi gen inang yang rentan pada saat persilangan, meningkatnya pertukaran produk pertanian secara global, jaringan transportasi antar benua, dan perubahan kondisi iklim global (Khan et al., 2014).

\section{KESIMPULAN}

Penyakit kuning pada tanaman mentimun di Jawa Barat dan Bali disebabkan oleh infeksi tunggal dan campuran Squash leaf curl China virus, Tomato leaf curl New Delhi virus, dan Ageratum yellow vein virus. ToLCNDV merupakan virus yang dominan menginfeksi mentimun di lapangan dengan insidensi penyakit 28-100\%. SLCCNV terdeteksi di Tabanan, Klungkung, Gianyar, Karawang, dan Sumedang dengan insidensi penyakit $30-80 \%$. Keberadaan SLCCNV pada pertanaman mentimun di Jawa Barat dan infeksi ganda antara ToLCNDV dan SLCCNV di Jawa Barat dan Bali merupakan temuan baru dari penelitian ini. Berdasarkan analisis runutan nukleotida dan asam amino gen protein selubung diketahui bahwa ToLCNDV dan SLCCNV pada tanaman mentimun di Jawa Barat dan Bali adalah ToLCNDV strain Indonesia dan SLCCNV strain China.

\section{DAFTAR PUSTAKA}

Aidawati, N., S.H. Hidayat, R. Suseno, P. Hidayat, S. Sujiprihati. 2005. Identifikasi Geminivirus yang menginfeksi tomat berdasarkan pada teknik polymerase chain reaction-restriction fragment length polymorphism. J. Mikrob. Indones. 10(1): 29-32.

Al-Musa, A., G. Anfoka, S. Misbeh, M. Abhary, F.H. Ahmad. 2008. Detection and molecular characterization of Squash leaf curl virus (SLCV) in Jordan. J. Phytopathol. 156: 311-316. DOI: $10.1111 /$ j.1439-0434.2007.01389.x. 
Anggraini, S., S.H. Hidayat. 2014. Sensitivitas metode serologi dan polymerase chain reaction untuk mendeteksi Bean common mosaic Potyvirus pada kacang panjang. J. Fitopatol. Indones. 10(1): 17-22.

Brown, J.K., C.M. Fauquet, R.W. Briddon, M. Zerbini, E. Moriones, J. Navas-Castillo. 2012. Family Geminiviridae. p. 351373. In M.Q.A. Kings, M.J. Adams, E.B. Carstens, E.J. Lefkowitz, (eds). Virus Taxonomy: Ninth Report of the International Committee on Taxonomy of Viruses. Elsevier, Inc.

Doyle, J.J., J.L. Doyle. 1987. A rapid DNA isolation procedure for small quantities of fresh leaf tissues. Phytochem. Bull. 19: 11-15.

Flock, R.A., D.E. Mayhew. 1981. Squash leaf curl, a new disease of cucurbits in California. Plant Dis. 65: 75-76.

Fondong, V.N., J.S. Pita, M.E.C. Rey, A.de Kochko, R.N. Beachy, C.M. Fauquet. 2000. Evidence of synergism between African cassava mosaic virus and a new double - recombinant geminivirus infecting cassava in Cameroon. J. Gen. Virol. 81: 287-297.

Khan, M.S., A.K. Tiwari, S.K. Raj, A. Srivastava, S.H. Ji, S.C. Chun. 2014. Molecular epidemiology of Begomovirus occuring on some vegetables, grain legume, and weed species in the Terai Belt of North India. J. of Plant Dis. Protec. 121(2): 53-57.

Kintasari, T., D.W.N. Septariani, S. Sulandari, S.H. Hidayat. 2013. Tomato yellow leaf curl Kanchanaburi virus penyebab penyakit mosail kuning pada tanaman terung di Jawa. J. Fitopatol. Indones. 9(4): 127-131.

Maruthi, M.N., A.R. Rekha, V. Muniyappa. 2007. Pumpkin yellow vein mosaic disease is caused by two distinct Begomoviruses: complete viral sequences and comparative transmission by an indigenous Bemisia tabaci and the introduced B-biotype. Bulettin OEPP/EPPO Bulletin 37:412-419.

Méndez-Lozano, J., I. Torres-Pacheco, C.M. Fauquet, R.F. Rivera-Bustamant. 2003. Interactions between Geminiviruses in a naturally occurring mixture: Pepper huasteco virus and Pepper golden mosaic virus. Phytopathol. 93: 270-277.

Mizutani, T., B.S. Daryono, M. Ikegami, K.T. Natsuaki. 2011. First report of Tomato leaf curl New Delhi virus infecting cucumber in Central Java, Indonesia. Disease Notes. 95(11): 1485.

Nurulita, S., S.H. Hidayat, K.H. Mutaqin, J. Thomas. 2015. Molecular characterization of Begomovirus infecting yard long bean (Vigna unguiculata subsp. sesquipedalis L.) in Java, Indonesia. Biotropia. 22(1): 53-60. DOI: 10.11598/ btb.2015.22.1.401

Pratap, D., A.R. Kashikar, S.K. Mukherjee. 2011. Molecular characterization and infectivity of a Tomato leaf curl New Delhi virus variant associated with newly emerging yellow mosaic disease of eggplant in India. Virol. J. 8(305): 113.

Revill, P.A., C.V. Ha, S.C. Porchun, M.T. Vu, J.L. Dale. 2003. The complete nucleotide sequence of two distinct Geminiviruses infecting cucurbits in Vietnam. Archiv. Virol. 148: 15231541.

Ringwald, T.S., M. Lapidot. 2011. Characterization of a synergistic interaction between two Cucurbitinfecting Begomoviruses: Squash leaf curl virus and Watermelon chlorotic stunt virus. Phytopathol. 101(2): 281289. DOI: 10.1094/PHYTO-06-10-0159.

Santoso, T.J., S.H. Hidayat, M. Herman, Sudarsono. 2013. Aplikasi teknik Polymerase Chain Reaction (PCR) menggunakan primer Degenerate dan spesifik Gen $A V l$ untuk mendeketsi Begomovirus pada tomat (Lycopersicon 
esculentum Mill.). J. Hort. Indonesia. 4(3): 140-149.

Septariani, D.N., S.H. Hidayat, E. Nurhayati. 2014. Identifikasi penyebab penyakit daun keriting pada tanaman mentimun. Jurnal Hama Penyakit Tumbuhan Tropika. 14(1): 80-86.

Singh, R., S.K. Raj, V. Prasad. 2008. Molecular characterization of a strain of Squash leaf curl China Virus from North India. J. of Phytopathol. 156: 222-228. DOI: $10.1111 /$ j.1439-0434. 2007.01347.x.

Sulandari, S., R. Suseno, S.H. Hidayat, J. Harjosudarmo, S. Sosromarsono. 2006. Deteksi dan kajian inang virus penyebab penyakit daun keriting kuning cabai. Hayati. 13(1): 1-6.

Tahir, M., M.S. Haider, R.W. Briddon. 2010. First report of Squash leaf curl China virus in Pakistan. Austr. Plant Dis. Notes. 5: 21-24.
Tamura, T., G. Stecher, D. Peterson, A. Filipski, S. Kumar. 2013. MEGA6: Molecular Evolutionary Genetics Analysis Version 6.0. Mol. Biol. Evol. 30(12): 2725-2729.

Tiwari, A.K., P.K. Sharma, M.S. Khan, S.K. Raj, G.P. Rao. 2010. Molecular detection and identification of Tomato leaf curl New Delhi virus isolate causing yellow mosaic disease in Bitter gourd (Momordica charantia), a medicinally important plant in India. Medicinal Plants. 2(2): 117-123.

Wiratama, I.D.M.P., G.N.A.S. Wirya, N.N.P Anyani, I.D.N. Nyana, G. Suastika. 2015. Laporan pertama infeksi Begomovirus pada tanaman mentimun di Bali. J. Fitopatol. Indones. 11(5): 175178.

Wyatt, S.D., J.K. Brown. 1996. Detection of subgroup III Geminivirus isolates in leaf extracts by degenerate primers and polymerase chain reaction. Phytopathol. 86: $1288-1293$. 